\title{
Experimental Study on Maize Cob Trickling Filter-Based Wastewater Treatment System: Design, Development, and Performance Evaluation
}

\author{
Imran Ali', Zahid M. Khan', Muhammad Sultan ${ }^{1 *}$, Muhammad H. Mahmood ${ }^{1,2}$, \\ Hafiz U. Farid ${ }^{1}$, Mohsin Ali ${ }^{3}$, Abdul Nasir ${ }^{4}$ \\ 'Department of Agricultural Engineering, Bahauddin Zakariya University, \\ Bosan Road, Multan 60800, Pakistan \\ ${ }^{2}$ International Institute for Carbon-Neutral Energy Research (WPI-I'I CNER), \\ Kyushu University, 744 Motooka, Nishi-ku, Fukuoka 819-0395, Japan \\ ${ }^{3}$ Department of Environmental Engineering, Middle East Technical University, \\ Ankara 0600, Turkey \\ ${ }^{4}$ Faculty of Agricultural Engineering and Technology, University of Agriculture, \\ Faisalabad, Pakistan
}

Received: 23 April 2016

Accepted: 11 June 2016

\begin{abstract}
In developing countries, good-quality water is contaminated due to the disposal of untreated municipal and industrial wastewater (WW) into natural water reservoirs. Most of the wastewater is not treated properly according to international standards, and usually is disposed of and/or utilized for irrigation without appropriate treatment. The main hurdles in providing wastewater treatment (WWT) in developing countries include high costs, and the poor design, installation, and operation of conventional WWT systems. Therefore, the present study explores the maize cobs trickling filter-based (MCTF) low-cost WWT option for developing countries like Pakistan, India, and Bangladesh. In this regard, indigenous media trickling filter was designed and developed using maize cobs as packing material for biofilm growth. The MCTFWWT system was continually operated and monitored for six months at constant hydraulic wastewater loading of about $113 \pm 2 \mathrm{~m}^{3}$ per $\mathrm{m}^{2}$ per day. The experimental data covers winter and summer seasons with temperature variations from $23^{\circ} \mathrm{C}$ to $43^{\circ} \mathrm{C}$. System performance was evaluated by means of various WWT parameters, including biological and chemical oxygen demands ( $\mathrm{BOD}_{5}$ and $\left.\mathrm{COD}\right)$, total suspended and dissolved solids (TSS and TDS), turbidity, and color - before and after WWT. Experimental results showed that the MCTF-WWT system successfully removed about 79\% BOD and 75\% COD on average. The key reason for effective BOD and COD removal was rapid development of microbial film (within the first two
\end{abstract}

*e-mail: muhammadsultan@bzu.edu.pk 
weeks). Furthermore, the MCTF-WWT system removed 42-46\% TSS, $28-30 \%$ TDS, $43-46 \%$ turbidity, and $33-37 \%$ color. The study concludes that the MCTF-WWT system is an effective and economical WWT option for irrigation/agricultural applications in developing countries.

Keywords: wastewater, maize cobs, trickling filter, treatment, developing countries

\section{Introduction}

Water is becoming a scarce resource in developing countries like Pakistan, India, and Bangladesh due to the disposal of untreated municipal and industrial wastewater (WW) into natural water reservoirs. In this regard, experts are trying all possible environmentally friendly options to provide additional water sources for developing countries that can be used economically for agricultural and/or domestic applications [1]. Meanwhile, the requirements for food production are continuously increasing due to high population growth [2-3]. In this situation, supplemental WW use in irrigated agriculture is becoming essential to cope with increasing water scarcity. However, use of untreated WW in irrigated agriculture could have a number of negative impacts due to WW contaminants that may get incorporated into agricultural produce. In addition, the quality of surface and groundwater sources has also deteriorated due to the disposal of untreated municipal and industrial effluent into natural receiving water bodies [4]. The pollutants from wastewater may also accumulate in the farm soil and aid the development of a disease vector's habitats such as mosquitoes and flies [5-6]. Such negative aspects can be controlled and possibly eliminated through effective wastewater treatment (WWT) in order to provide safe WW utilization in agriculture. In developing countries, limited WWT facilities are in practice due to economic and social constraints [7]. According to a study, only $5-8 \%$ of domestic and industrial wastewaters receive treatment in Pakistan before its reuse [8-10]. The main hindrance in construction and installation of WWT systems is cost, energy, trained human resources, and operational complications [11-12]. To resolve these issues, several options may be adopted such as trickling filters, cascade aeration, adsorption filters, oxidation ditches, aerated ponds, etc.

The trickling filters are technically less complex as compared to other biological WWT systems [13]. These are resilient against power failures and shock loads, and possess a small environmental footprint. It enables simple design considerations and requires relatively lower installation cost, energy, land area, repair, and maintenance. Therefore, implementation of a trickling filter is an attractive biological treatment option for WW. It is an attached growth biological process in which the biofilm/microbial community resides on the rock/plastic packing in the trickling filters. It contains microorganisms for the biodegradation of the substrates to remove these substrates from the wastewater. The microbial community contains aerobic and facultative bacteria, fungi, algae, and protozoans [14-15]. Many factors affect the aerobic zone of the biofilm such as organic substrate, oxygen concentration, temperature, ventilation, wastewater $\mathrm{pH}$, and characteristics of filter media including size, depth, weight, specific surface area, and void ratio, etc. [16-17].

Therefore, media selection is also an important factor for improving the performance efficiency of a trickling filter. Effective media plays a key role in the development of microbial community/biofilm. Several biofilm support media have been used to increase the performance of a trickling filter, such as rocks/plastic [14], a nylon pot scrubber[18], commercial rings (e.g., crushed leca, kaldnes, and Norton), calcitic gravel [15-16], luffa cylindrical [19], geotextile [20], pall rings [21], polyurethane foam pores [22], coal cinder [23], tire-derived drubber [24], oyster shell [25], corrugated plastic sheet [26], stone [27], gravel and zeolite [28], sponge [29], zeolite and ceramsite [30], polypropylene plastic [31], biochar chips [32], and ceramic particles [33]. These are either costly or not easily available by small landholder farmers. Most of these materials (e.g., plastic, geotextiles, commercial rings, polyurethane foam, tire-derived rubber, sponge, biochar chips, and ceramics) are being prepared synthetically and cannot work without introducing specific seeding/ acclimatization of the microbial community. It would eventually increase operational costs of the treatment system [14-33]. Moreover, technically trained human power is required to operate the treatment systems and also not easily available by the small landholder farmers. On the other hand, indigenous materials generated from agricultural wastes can be used as biofilm support media to improve trickling filter performance efficiency. In this regard, the present study focuses on maize cobs, which is the waste generated by processing corn. According to a study in 2006, the worldwide annual production of maize cobs is about $520 \times 10^{9} \mathrm{~kg}$ [34], which shows the scope of the study in developing countries.

In developing countries, maize cobs usually lead to severe management and environmental problems at farms, and therefore can be successfully utilized in trickling filter for WWT. The maize cobs have a filamentous structure, which may cause rapid attachment and development of the microbial community. It provides considerable specific surface area, high void ratio, and small specific gravity [35-36]. From the above prospective, a maize cobs trickling filter-based (MCTF) WWT system was designed and developed in the present study. MCTF-WWT system performance was evaluated by means of WW parameters of color, turbidity, biological and chemical oxygen demands $\left(\mathrm{BOD}_{5}\right.$ and $\left.\mathrm{COD}\right)$, and total suspended and dissolved solids (TSS and TDS) before and after the WW 
treatment.

\section{Experimental Section}

\section{Wastewater}

In the present study, wastewater samples were collected from sewage collection stations at Bahauddin Zakariya University in Multan, Pakistan. The WW samples were analyzed for various parameters before and after WW treatment. The COD and BOD were tested according to the standard methods described in APHA Standard Methods (2012) [37]. TSS, turbidity, and color were tested using a Spectroquant Multi (made in Germany, Sr. No. 11/4149). The temperatures of the samples were measured using $\mathrm{DO}^{+6}$ EuTech (Sr. No. 662684) in ${ }^{\circ} \mathrm{C}$, whereas he TDS were determined using an Eco Tester TDS Low.

\section{Biofilm Support Media}

Biofilm support media (i.e., maize cobs for the MCTFWWT system) were obtained from an agricultural site in Multan. Pictorial representation of maize cob shells with and without grains is shown in Fig. 1. Maize cobs are initially dried in an oven and cut into equal-sized pieces having length $(h)$ and diameter $(d)$ of $7.97 \mathrm{~cm} \pm 0.30 \mathrm{~cm}$ and $2.54 \mathrm{~cm} \pm 0.20 \mathrm{~cm}$, respectively. Prepared maize cobs are dipped into distilled water and washed carefully. Cleaned maize cob shells are then dried in an oven at $105^{\circ} \mathrm{C}$ for $5 \mathrm{hr}$. After that these were sterilized at $16 \mathrm{psi}$ for $30 \mathrm{~min}[23,32]$. Surface area and volume of the maize cobs was calculated using the following slandered equations, i.e., $A=2 \pi r(r+h)$ and $V=\pi r^{2} h$. The parameters $r$ and $h$ represent the radius and height of the maize cobs, respectively, as mentioned in Fig. 1 and Table 1. It was found that average specific area and volume of maize cob shells was $167.64 \mathrm{~cm}^{2}$ and $161.45 \mathrm{~cm}^{3}$, respectively. The specific surface area of the maize cob was determined by dividing the surface area with volume of the maize cob, which was $1.03 \mathrm{~cm}^{2} / \mathrm{cm}^{3}$. The characteristics of the maize cobs packing material are given in Table 1 .

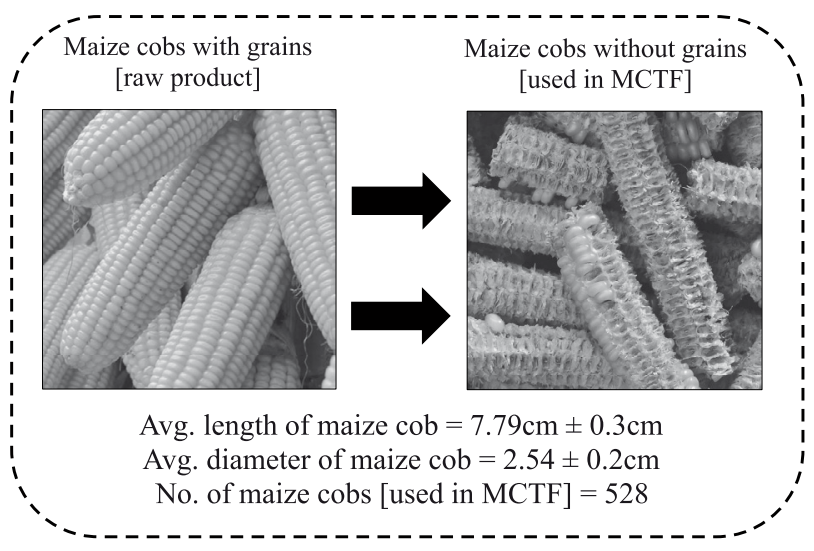

Fig. 1. Pictorial representation of maize cob shells with (left) and without (right) grains.
Table 1. Characteristics of the maize cobs as biofilm support media.

\begin{tabular}{|c|c|c|}
\hline Parameters & Unit & Value \\
\hline length (average) & {$[\mathrm{cm}]$} & $7.97 \pm 0.3$ \\
\hline diameter (average) & {$[\mathrm{cm}]$} & $2.54 \pm 0.2$ \\
\hline $\mathrm{pH}$ (average) & {$[-]$} & 6.11 \\
\hline $\begin{array}{c}\text { average moisture content (at } \\
\text { field capacity) }\end{array}$ & {$[\%]$} & 58.6 \\
\hline $\begin{array}{c}\text { dry filled weight (average) } \\
\text { specific surface area } \\
\text { (average) }\end{array}$ & {$[\mathrm{g}]$} & 192 \\
\hline true density (average) & {$\left[\mathrm{cm}^{3}\right]$} & 1.03 \\
\hline porosity (average) & {$\left[\% / \mathrm{cm}^{3}\right]$} & 1.18 \\
\hline $\mathrm{C}: \mathrm{H}: \mathrm{N}: \mathrm{S}$ & {$[\%]$} & $65.3: 7.1: 0: 0$ \\
\hline
\end{tabular}

\section{MCTF-WWT System Setup and Procedure}

The body of the MCTF-WWT system was fabricated in the university's departmental workshop using a gauge $22=0.64 \mathrm{~mm} \mathrm{Zn}$ alloy-based metallic sheet in a circular shape with $76.2 \mathrm{~cm}$ diameter and $152.4 \mathrm{~cm}$ high. The schematic diagram of the developed MCTF-WWT system is shown in Fig. 2. Latitude and longitude values of the installed MCTF-WWT system are $30.2639^{\circ} \mathrm{N}$ and $71.5101^{\circ} \mathrm{E}$. The drainage layer having depth of $30.48 \mathrm{~cm}$ was laid on the bottom of the reactor body as shown in Fig. 2. The drainage layer in the MCTF-WWT system was designed with rocks having slotted tops to admit the WW and support the media. It served three functions: (i) to transmit the wastewater passing through the filter, (ii) to slough solids from the filter to the settling tank, and (iii) to maintain aerobic conditions by supplying ventilation to the filter. The MCTF-WWT system was packed with maize cob filter media as packing material on top of the drainage layer in order to support the biofilm. The packing material maize cobs was installed gently to ensure zero/ minimum breakage during installation. The media was supported by a circular steel grid that rested at $30.48 \mathrm{~cm}$

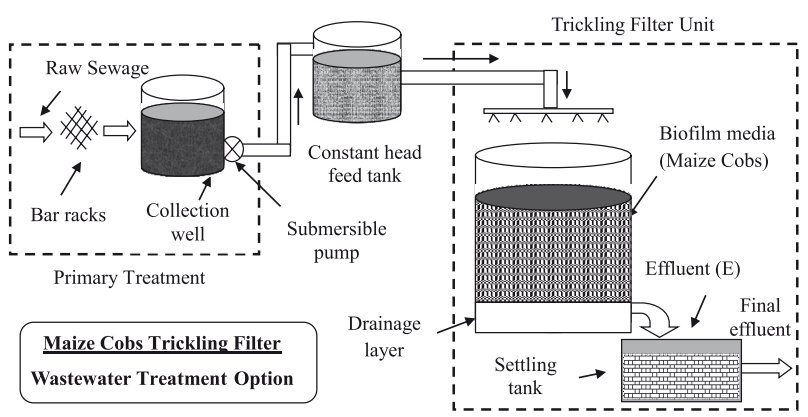

Fig. 2. Schematic diagram of the developed MCTF-WWT system. 
above the bottom of the filter. The grid was constructed in a circular section using steel strips. The depth of the media in MCTF was $137.16 \mathrm{~cm}$ with effective volume of $0.62 \mathrm{~m}^{3}$ $[14,16,23]$.

After the development of biofilm growth on maize cobs, the developed MCTF-WWT system was operated at constant hydraulic loading rate (HLR) of $113 \pm 2 \mathrm{~m}^{3} / \mathrm{m}^{2} /$ day for six months with variable organic loading of about 9 to $20 \mathrm{~kg} \mathrm{BOD} / \mathrm{m}^{3} /$ day. The $\mathrm{WW}$ distribution in the MCTF-WWT system was kept constant for each run. The hydraulic loading rate was increased twice a week up to $151.68 \mathrm{~m}^{3} / \mathrm{m}^{2} /$ day in order to flush out the possible solids accumulated in the media. The removal efficiencies $(\eta)$ were calculated using the following relationship $[15,27,33]$ :

$$
\eta(\%)=\left(\frac{C_{\text {in }}-C_{\text {out }}}{C_{\text {in }}}\right) 100
$$

...where $\mathrm{C}_{\text {in }}[\mathrm{mg} / \mathrm{l}]$ and $\mathrm{C}_{\text {out }}[\mathrm{mg} / \mathrm{l}]$ are the influent and effluent concentrations, respectively.

\section{Results and Discussion}

One month prior to the experiments, the wastewater samples were collected from the sampling cites (as described previously) and analyzed for various WWT parameters in order to establish the basic knowhow about wastewater and sampling sites. The influent composition has been determined and the corresponding results are given in Table 2. It can be seen that the resulting BOD and COD ranged from $103 \mathrm{mg} / \mathrm{L}$ to $276 \mathrm{mg} / \mathrm{L}$ and $124 \mathrm{mg} / \mathrm{L}$ to $300 \mathrm{mg} / \mathrm{L}$, respectively. In addition, the TSS and TDS was found to be about $80 \mathrm{mg} / \mathrm{L}$ to $111 \mathrm{mg} / \mathrm{L}$ and $590 \mathrm{mg} / \mathrm{L}$ to $698 \mathrm{mg} / \mathrm{L}$, respectively. Therefore, the average WW composition indicates that it could be classified as medium type municipal sewage [14, 28]. Furthermore, average $\mathrm{BOD}_{5} / \mathrm{COD}$ was more than 0.80 , which indicates that the system didn't require any kind of acclimatized biomass for initial startup [33, 38].

After packing maize cobs media into the MCTF-

Table 2. Influent composition of wastewater collected from the sampling cites.

\begin{tabular}{|c|c|c|}
\hline Parameter & Range & Average \\
\hline $\begin{array}{c}\text { biological oxygen demand, BOD } \\
{[\mathrm{mg} / \mathrm{L}]}\end{array}$ & $103-276$ & 214 \\
\hline $\begin{array}{c}\text { chemical oxygen demand, COD } \\
{[\mathrm{mg} / \mathrm{L}]}\end{array}$ & $124-300$ & 250 \\
\hline $\begin{array}{c}\text { temperature }\left[{ }^{\circ} \mathrm{C}\right] \\
\text { total suspended solid, TSS [mg/L] }\end{array}$ & $23-43$ & 34 \\
\hline total dissolved solid, TDS [mg/L] & $590-698$ & 658 \\
\hline turbidity [FAU] & $603-699$ & 647 \\
\hline color [pt/co] & $103-276$ & 214 \\
\hline
\end{tabular}

WWT system, the system was fed with primary-treated wastewater using a constant head feed tank through $2.54 \mathrm{~cm}$ diameter PVC pipes as shown in Fig. 2. The constant head feed tank was plastic and installed exactly above the reactor. The feed tank was filled using a 1.5 hp submersible pump with a $10 \mathrm{~m}$ head. The influent was entered into the tank through PVC pipes, whereas the control valves were provided to adjust the constant hydraulic flow rate passing through the reactors. An additional PVC pipe of the same diameter was also installed above the feed tank, which gives it the provision to bypass the extra influent. The WW was sprinkled over the media for three weeks as a startup period in order to develop the biofilm. It was observed that the MCTFWWT system started to develop a biofilm layer just after 15 days of operation without biomass acclimatization. This is because the average value of influent $\mathrm{BOD}_{5} / \mathrm{COD}$ was more than 0.80 , which indicated that the WW didn't require any kind of pre-treatment or acclimate biomass [38]. Initially, the MCTF-WWT system was operated as batch reactor for a period of about 30 days to ensure fully attachment of the microbial community onto the support media maize cobs for proper biofilm development. Several operating cycles were performed until the MCTFWWT system reached full reduction of organic matter. It has been considered that the startup period of the MCTFWWT system was completed and the filters were ready for full operation.

During the active experiments on the MCTF-WWT system, the influent and effluent samples were collected at regular intervals for the performance evaluation of the system. The frequency of the sample collections and analytical methods employed for estimations are listed in Table 3. All the parameters were tested according to the standard protocol as mentioned in Table 3. The coming section will discuss the performance evaluation of the MCTF-WWT system for individual WWT parameters.

\section{COD and BOD Removal}

Biological and chemical oxygen demand (COD and BOD) tests were performed for performance evaluation of the developed MCTF-WWT system by reducing the pollution strength of municipal wastewaters. Results showed that the COD concentration in influent and effluent ranged from $124 \mathrm{mg} / \mathrm{L}$ to $300 \mathrm{mg} / \mathrm{L}$ (average $250 \mathrm{mg} / \mathrm{L}$ ), and $8 \mathrm{mg} / \mathrm{L}$ to $155 \mathrm{mg} / \mathrm{L}$ (average $67 \mathrm{mg} / \mathrm{L}$ ), respectively. However, the BOD concentration in influent and effluents ranged from $103 \mathrm{mg} / \mathrm{L}$ to $276 \mathrm{mg} / \mathrm{L}$ (average $214 \mathrm{mg} / \mathrm{L}$ ) and $5 \mathrm{mg} / \mathrm{L}$ to $129 \mathrm{mg} / \mathrm{L}$ (average $49 \mathrm{mg} / \mathrm{L}$ ), respectively. The developed MCTF-WWT system possessed COD removal efficiency of 52-96\% (average 75\%), and BOD removal efficiency of $51-96 \%$ (average $79 \%$ ). The detailed results are plotted in Figs. 3 and 4 for COD and BOD removal efficiencies, respectively. Referring to Figs. 3 and 4, we can notice that the developed MCTF-WWT system rapidly reduces $\mathrm{COD}$ and $\mathrm{BOD}$ pollutant strength after the formation of a slime layer on the maize cob filter media. This is due to the filamentous structure of the maize cob 
Table 3. Frequency of sample collections and analytical methods employed for estimating WWT parameters.

\begin{tabular}{|c|c|c|}
\hline Parameter & Methodology & Frequency \\
\hline $\begin{array}{c}\text { Biological oxygen } \\
\text { demand, BOD [mg/L] }\end{array}$ & $\begin{array}{l}\text { APHA Standard } \\
\text { Methods } \\
\text { (Method No. } \\
\text { 5210B) }\end{array}$ & Once a week \\
\hline $\begin{array}{c}\text { Chemical oxygen } \\
\text { demand, COD }[\mathrm{mg} / \mathrm{L}]\end{array}$ & $\begin{array}{l}\text { APHA Standard } \\
\text { Methods } \\
\text { (Open Reflux } \\
\text { Method, Method } \\
\text { No. 5220B) }\end{array}$ & $\begin{array}{l}\text { Thrice a } \\
\text { week }\end{array}$ \\
\hline Temperature $\left[{ }^{\circ} \mathrm{C}\right]$ & $\begin{array}{c}\mathrm{DO}^{+6} \text { EuTech } \\
\text { (Sr. NO. 662684) }\end{array}$ & Regular \\
\hline $\begin{array}{l}\text { Total dissolved solid, } \\
\text { TDS }[\mathrm{mg} / \mathrm{L}]\end{array}$ & $\begin{array}{c}\text { Eco Tester TDS } \\
\text { Low }\end{array}$ & $\begin{array}{l}\text { Thrice a } \\
\text { week }\end{array}$ \\
\hline $\begin{array}{c}\text { Total suspended solid, } \\
\text { TSS }[\mathrm{mg} / \mathrm{L}]\end{array}$ & \multirow{3}{*}{$\begin{array}{l}\text { Spectroquant } \\
\text { Multi } \\
\text { (made in } \\
\text { Germany, Sr. No } \\
\text { 11/4149) }\end{array}$} & $\begin{array}{l}\text { Thrice a } \\
\text { week }\end{array}$ \\
\hline Turbidity [FAU] & & $\begin{array}{l}\text { Thrice a } \\
\text { week }\end{array}$ \\
\hline Color [pt/co] & & $\begin{array}{c}\text { Thrice a } \\
\text { week }\end{array}$ \\
\hline
\end{tabular}

filter media that causes rapid attachments of microbes.

It is worth mentioning that the $\mathrm{COD}$ and $\mathrm{BOD}$ removal efficiencies were decreased during the MCTFWWT system operating days of 5 to 40 . This might be due to the accumulation of microbes on maize cob filter media, which increases slime layer thickness. Therefore, it maintains an anaerobic zone on the upper part of the biofilm, which slows down the degradation of organic substrates. Soon after 40 days of MCTF-WWT system operation, the COD and BOD removal efficiencies start increasing gradually with the passage of time as shown in Figs. 3 and 4, respectively. This is because the anaerobic zone was destroyed using proper flushing, by which the aerobic zone was maintained in the outer portion of the slime layer [39-42]. Therefore, in the present study after 40 days of MCTF-WWT system operation, $85-90 \%$ of $\mathrm{COD}$ and BOD removal efficiencies were yielded. In addition, $\mathrm{COD}$ and BOD removal efficiencies varied with respect to ambient air temperature as shown in Figs 3 and 4. The maximum COD and BOD removal efficiencies of $96 \%$ were achieved in summer, when temperature ranged $35-43^{\circ} \mathrm{C}$. On the other hand, minimum COD and BOD removal efficiencies were achieved in winter, when temperature ranged $23-28^{\circ} \mathrm{C}$.

Such behavior of COD and BOD removal efficiencies might be due to organic compound degradation by the microorganisms attached with MCTF media due to variations in ambient air temperature [20,31]. The increase in COD and BOD removal efficiencies was associated with the increase in temperature and the development of efficient biofilm on maize cobs. According to the experimental results, environmental temperature has a positive effect on biofilm development. This is because most of the bacteria flourish well in the temperature range

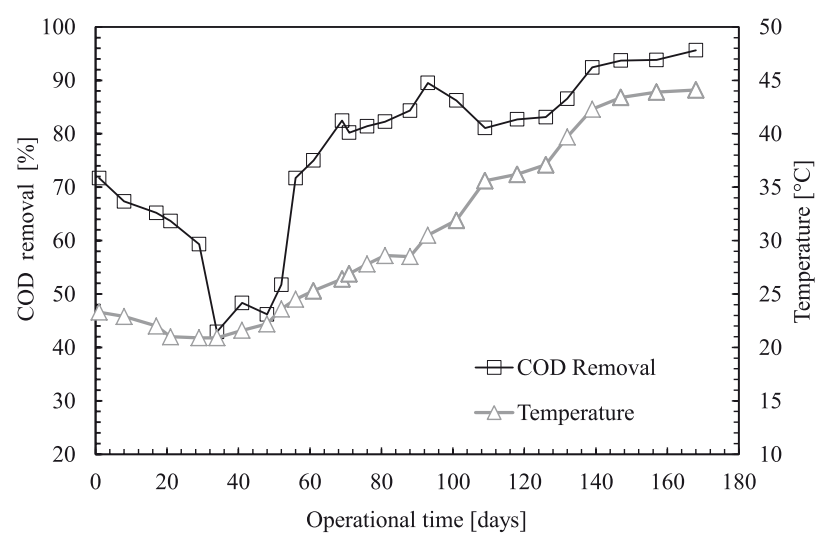

Fig. 3. COD removal efficiency profile observed through the MCTF-WWT system.

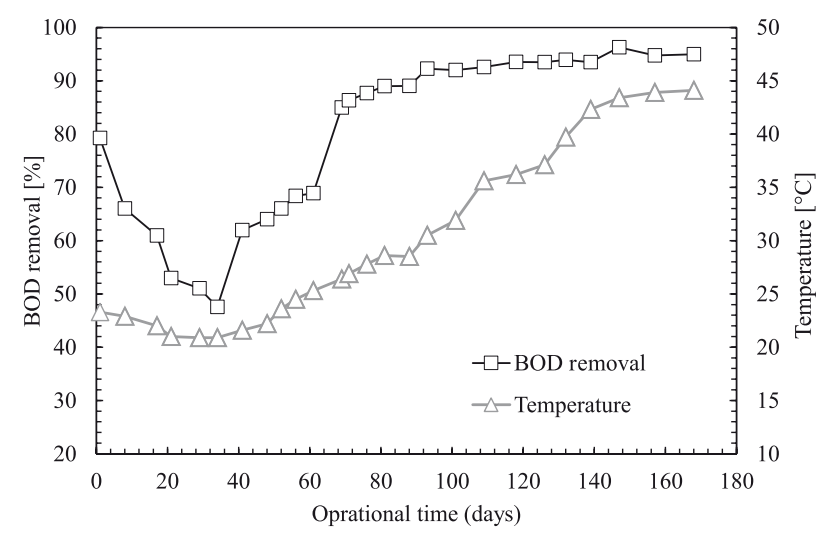

Fig. 4. BOD removal efficiency profile observed through the MCTF-WWT system.

$25-40^{\circ} \mathrm{C}$. Thus, it contributes to the removal of more pollutants from wastewater as their food [25, 33, 42]. Moreover, experimental results confirmed that ambient air temperature fluctuation can affect the organic compound degradation present in influent concentration and that is consequently yielded in variations of COD and BOD removal efficiencies.

Most often in trickling filter-based WWT systems, natural ventilation is the primary source of airflow within the filter. This is because the driving force for airflow is the temperature difference between the ambient air and the air inside the pores. It is worth mentioning that the airflow direction will be downward when the wastewater is cooler than the ambient air, whereas it will be upward when the ambient air is cooler than the wastewater. Therefore, higher values of COD and BOD removal efficiencies were yielded in summer due to higher oxygen availability for maintaining the aerobic zone in the outer portion of slime layer that also leads to organic substrate degradation. Similarly, the lower values of COD and BOD removal efficiencies obtained in winter season were due to the low oxygen availability, which ultimately increases slime layer thickness and establishes an anaerobic zone in the outer portion of the slime layer. The formation of an 
anaerobic zone decreases the full degradation of organic substrates before it has been discharged from the MCTFWWT system [43-45]. In addition, maize cobs were degraded during the experiments but no notable impact was observed on BOD and COD removal efficiencies during the study period. This might be due to periodic flushing of the filter media maize cobs, which eventually help to replenish the aerobic environment during system operation. A similar study was conducted using corn cobbased biogenic filter material in the biofilter system [46]. According to the results presented in [46], COD and BOD removal efficiencies of $75-78 \%$ were yielded at different hydraulic retention times. Therefore, the present study on MCTF has advantages over the corn cob-based trickling filters, and can be beneficial for establishing a low-cost WWT system, especially for developing countries.

\section{TSS Removal}

Determining total suspended solids (TSS) in any WWT system is very important in order to emphasize the physical states of principal WW constituents [15, 27]. The value of TSS in influent was in the ranges of $80-111 \mathrm{mg} / \mathrm{L}$ with an average of $101 \mathrm{mg} / \mathrm{L}$. After treatment by the MCTF-WWT system, the TSS effluent concentration ranged 44-63 mg/L with an average of $52 \mathrm{mg} / \mathrm{L}$ (Fig. 5). According to the experimental results, the MCTF-WWT system achieved an average TSS removal efficiency of about $46 \%$. The system removed TSS up to $44 \mathrm{mg} / \mathrm{L}$ with maximum removal efficiency of $56 \%$ (Fig. 5). The MCTF-WWT system possesses rise and fall in TSS removal efficiency during the study period, which could be due to the accumulation of sloughed off biomass and/or solid dragging from the maize cob filter media in effluent during the treatment process. Many researchers have identified that the COD, TSS, and TDS are directly related to electrical conductivity (EC) [4748]. The larger the number of suspended solids in WW, the higher will be the wastewater EC and vice versa. In this study it has been observed that the MCTF-WWT system removed TSS with respect to COD reduction, and

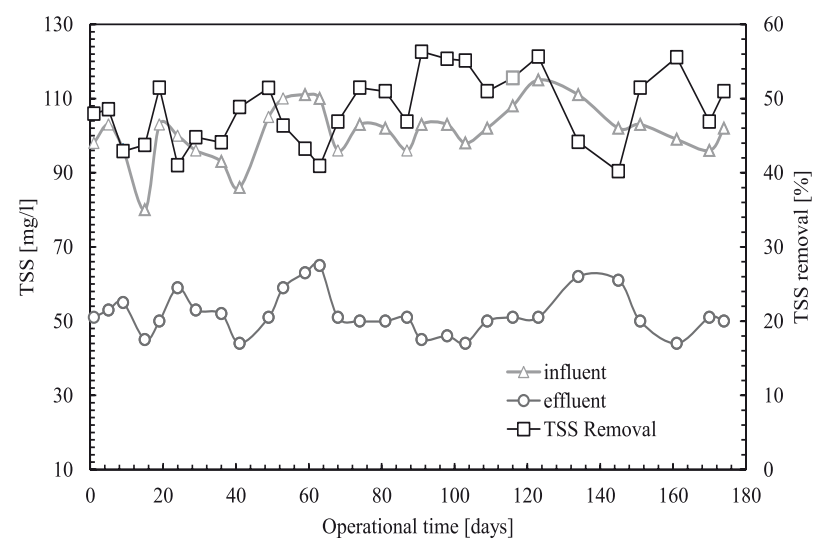

Fig. 5. TSS removal efficiency profile observed through the MCTF-WWT system. the TSS concentration is reduced with the decrement in COD concentration. Finally, the study concludes that the MCTF-WWT system possesses a reasonable TSS removal efficiency, and the system can be utilized efficiently for WWT in developing countries.

\section{TDS Removal}

TDS is also an important parameter in WWT, which indicates the physical state of the principal WW constituents. In this study, the TDS concentration in influent ranged 589-697 $\mathrm{mg} / \mathrm{L}$, with an average $657 \mathrm{mg} / \mathrm{L}$ (Fig. 6). According to the experimental results, the developed MCTF-WWT system yielded a TDS effluent concentration of about $358 \mathrm{mg} / \mathrm{L}$ to $455 \mathrm{mg} / \mathrm{L}$, with an average of $412 \mathrm{mg} / \mathrm{L}$ (Fig. 6). It can be seen that the TDS removal efficiency of the MCTF-WWT system was fluctuating throughout the observation period and ranged $17-43 \%$. Moreover, it has been found that the ability of the MCTF-WWT system to remove TDS was gradually increasing with the operational time, and maximum removal efficiency of $41-43 \%$ can be achieved after 100 days of operation (Fig. 6). However, the average TDS removal efficiency was limited to $37 \%$. Conversion of $\mathrm{NO}_{3}$ into diatomic molecular nitrogen $\left(\mathrm{N}_{2}\right)$ is probably the key reason behind TDS concentration decrement, which also decreases wastewater EC [49]. Similarly, many studies have verified the connection of TDS with wastewater EC [47]. The study concluded that the MCTFWWT system can remove a reasonable amount of TDS and consequently could be a handy solution for WWT in developing countries.

\section{Turbidity Removal}

Turbidity is another important physical parameter of WWT that may cause pathogen growth leading to outbreaks of waterborne diseases [30]. In this study the value of influent turbidity was 52-93 FAU (Fig. 7). It can be seen that the average turbidity value of untreated WW was very high (i.e., $85 \mathrm{FAU}$ ), which could be due to

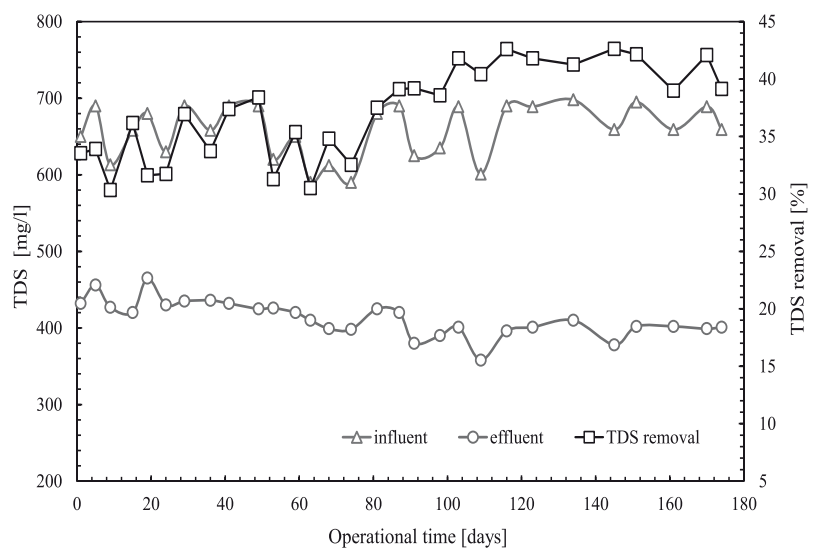

Fig. 6. TDS removal efficiency profile observed through the MCTF-WWT system. 


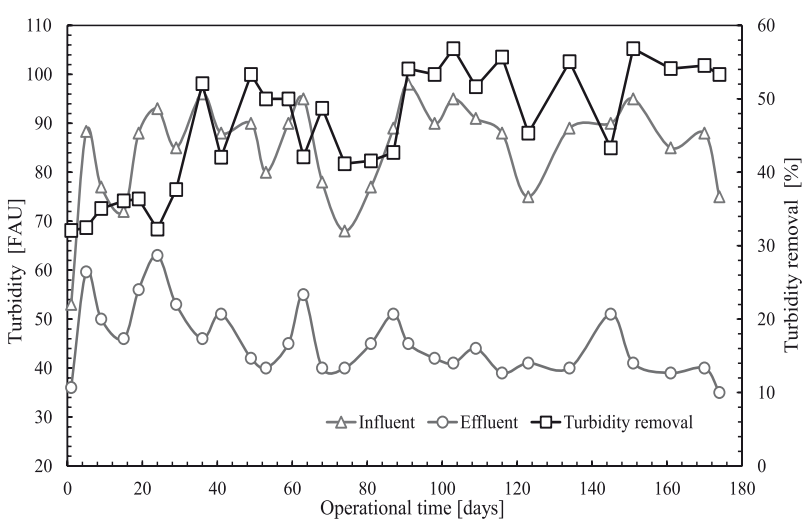

Fig. 7. Turbidity removal efficiency profile observed through the MCTF-WWT system.

the presence of particulate and organic matters in WW. The experimental results showed that the MCTF-WWT system removed turbidity up to 35 FAU to 63 FAU, with an average of 45 FAU (Fig. 7). Similar to TDS, the ability of the MCTF-WWT system to remove turbidity increases with the increased operational time. The average turbidity removal efficiency of $46 \%$ was achieved by the system while possessing the maximum of $57 \%$ after 100 days of operation. Such behavior of turbidity removal by the MCTF-WWT system is due to the degradation of compounds in WW by microorganisms attached to maize cob filter media [49-50]. It has been observed that turbidity removal efficiency is associated with COD concentration, and decreases with the decrease in COD concentration and vice versa [47]. The study concludes that the developed MCTF-WWT system can remove the WW turbidity sensibly, which could lead toward the development of a low-cost WWT system for developing countries.

\section{Color Removal}

Color removal in WW is also important due to the elimination of visible pollutants [51]. The primary concern about removing color from WW is not only its toxicity, but

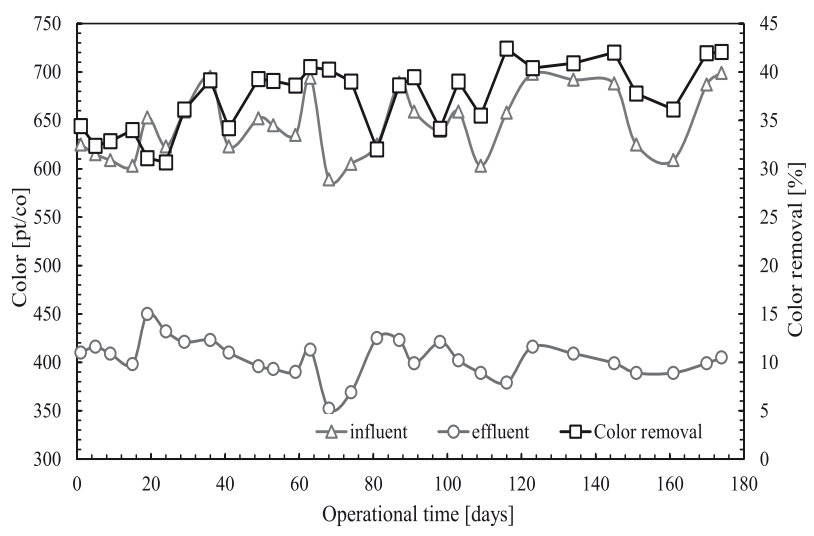

Fig. 8. Color removal efficiency profile observed through the MCTF-WWT system. also its undesirable aesthetic impact on receiving waters [52-53]. In the present study, influent color concentration was 603-699 pt/co with an average of 647 pt/co (Fig. 8). Results showed the MCTF-WWT system removed color concentration up to $352 \mathrm{pt} / \mathrm{co}$ to $450 \mathrm{pt} / \mathrm{co}$ with an average of $404 \mathrm{pt} / \mathrm{co}$. The color removal efficiency of the system was $31-42 \%$, with an average of $37 \%$. As the true color of WW is usually associated with dissolved organics, minerals and/or chemicals in WW, the key factors of color removal in the present work are reduction in TSS, TDS, and turbidity. Furthermore, it can also be due to adsorption capability of the maize cobs filter media [54]. We concluded that the developed MCTF-WWT system can be a low-cost solution for color removal in WWT for developing countries.

\section{Conclusions}

In the present study we designed and developed a simple and low-cost maize cobs tricking filter-based (MCTF) wastewater treatment (WWT) system for developing countries like Pakistan, India, and Bangladesh. In this regard, wastewater (WW) samples were collected from sewage collection stations located at Bahauddin Zakariya University. The WW samples were analyzed for various parameters (including COD, BOD, TSS, TDS, turbidity, and color) before and after WW treatment using the MCTF-WWT system. The MCTF was packed with maize cob shells obtained from an agricultural site. The maize cobs were used as support media for biofilm growth in the MCTF-WWT system. The system was operated for six months in order to evaluate its performance for various WWT parameters.

According to the experimental results, the MCTFWWT system successfully removed about $79 \%$ BOD and $75 \%$ COD on average. The key factor for effective BOD and COD removal was rapid development of microbial film (within the first two weeks). This is probably due to the filamentous structure, relatively high specific surface area, and inter-cob voids of the maize cob packing material. It is worth mentioning that the developed system solves the problems faced by conventional filter media such as the slow start up of biofilm. In addition to COD/ BOD, the system removed $42-46 \%$ TSS, $28-30 \%$ TDS, $43-46 \%$ turbidity, and $33-37 \%$ color on average. The study concludes that the maize cobs-based trickling filters could establish efficient and low-cost WWT systems for developing countries. Moreover, the treated WW from the MCTF-WWT system can be effectively utilized for irrigation/agricultural applications in developing countries.

\section{Acknowledgements}

The authors acknowledge support from the sewage disposal station staff during monitoring and collection of wastewater samples. The authors also acknowledge 
the Agricultural Engineering Department of Bahauddin Zakariya University for providing assistance and facilitating the experimental fieldwork.

\section{References}

1. NABEELA F., AZIZULLAH A., BIBI R., UZMA S., MURAD W., SHAKIR S.K., ULLAH W., QASIM M., HADER D.P. Microbial contamination of drinking water in Pakistan - a review. Environ Sci. Pollut. Res. Int. 21 (24), 13929, 2014.

2. MUSTAFA D., SAWAS A. Urbanisation and Political Change in Pakistan: exploring the known unknowns. Third World Quarterly. 34 (7), 1293, 2013.

3. GOP. Pakistan economic survey 2014-15 Ministry of Finance, Government of Pakistan, Pakistan. 64, 2015.

4. ULLAH H., KHAN I. Effects of sewage water irrigation of cabbage to soil geochemical properties and products safety in peri-urban Peshawar, Pakistan. Environ. Monit. Assess. 187 (3), 1, 2015

5. MURTAZA G., GHAFOOR A., QADIR M. Disposal and use of sewage on agricultural lands in Pakistan-a review, Pedosphere, 20 (1), 23, 2010.

6. AZIZULLAH A., KHATTAK M. N. K., RICHTER P. Water pollution in Pakistan and its impact on public health-a review. J. Environ. Intl, 37 (2), 479, 2011.

7. YASAR A., ZAKRIA M., BARI T. A., AFZAAL M. Cost - benefit analysis of using treated sewage for landscaping in Lahore city, Pakistan. Desalination and Water Treatment. 1-9, 2015.

8. FATIMA S.S., KHAN S.J. Evaluating the treatment performance of a full scale Activated Sludge Plant in Islamabad, Pakistan. Water Practice and Tech. 7 (1), 2012.

9. SHAH M., HASHMI H.N. Macrophyte waste stabilization ponds: An option for municipal WW treatment. Int. J. Phy. Sci. 7 (30), 5162, 2012.

10. KHAN M.A., LANG M., SHAUKAT S.S., ALAMGIR A., BALOCH T. Water Quality Assessment of Hingol River, Balochistan, Pakistan. Middle-East J. Sci. Res. 9 (2), 306, 2014

11. WISNIEWSKI C. Membrane bioreactor for water reuse. Desalination. 203 (1), 15, 2007.

12. RAJA S., CHEEMA H. M.N., BABAR S., KHAN A.A., MURTAZA G., ASLAM U. Socio-economic background of wastewater irrigation and bioaccumulation of heavy metals in crops and vegetables. Agri. Water Manag. 158, 26, 2015.

13. NAZA I., WAJID U., SHAMA S., ABDUL R., ZIA U.K., NAEEM A., SAFIA A. Performance evaluation of stonemedia pro-type pilot-scale trickling biofilter system for municipal wastewater treatment. Desalination and Water Treatment. 1, 2015.

14. METCALF E. Wastewater Engineering: Treatment, Disposal, and Reuse. $4^{\text {th }}$ edition. The McGraw-Hill Companies. New York. 2003.

15. EDING E.H., KAMSTRAB A., VERRETH J.A J. Design and operation of nitrifying trickling filters in recirculating aquaculture: A review. Aqua. Eng. 34 (3), 234, 2006.

16. ODD I.L., HELGE K. Efficiency of nitrification in trickling filters using different filter media. Aqua. Eng. 21 (3), 181, 2000.

17. SANDEEP M., BALENDU G., KIRAN P. Bioreactors for treatment of VOCs and odours-a review. J.Environ. Manage. 91 (5), 1039, 2010.

18. SANJIB M., MOHD T., MUKHERJEE C.K. Evaluation of nitrification performance of a trickling filter with nylon pot scrubber as media. I.J.S.N. 2, 2011.

19. MARCOS R., VIANNA. Wastewater treatment in trickling filters using luffa cyllindrical as biofilm supporting medium. J. Urb. Environ. Eng. 6, (2), 2012

20. MAHMOODA., LALEHY., CATHERINE N., MULLIGAN. Development of biofilm on geotextile in a new multi-zone wastewater treatment system for simultaneous removal of COD, nitrogen and phosphorus. Bioresour. Technol. 107, 78, 2012.

21. MAIKEL F., MARTÍN R., ROSA M. Hydrogen sulphide removal from biogas by an anoxic biotrickling filter packed with Pall rings. Chem. Eng. J. 225, 456, 2013.

22. WANG J., SHI H., QIANY. Wastewater treatment in a hybrid biological reactor (HBR): effect of organic loading rates. Process Biochem. 36 (4), 297, 2000.

23. QINGLIANG Z., HUIYUAN Z., KUN W. Removal and transformation of organic matters in domestic wastewater during lab-scale chemically enhanced primary treatment and a trickling filter treatment. J. Environ. Sci. 25 (1), 59, 2013.

24. NAZ I., KHATOON N., ALI M., SAROJ D., BATOOL S., ALI N. Appraisal of the tire derived rubber (TDR) medium for wastewater treatment under aerobic and anaerobic conditions. J. Chem. Tech. Biotech. 89 (4), 587, 2014.

25. HONGBING L., GU H., XIAOYING F., XIAOLING L., DAOCAI Z., JIAN P., KE Z., BO H., LIANGQIAN F., FENGHUI C., XIUBO S. Waste oyster shell as a kind of active filler to treat the combined wastewater at an estuary. J. Env. Sci. 25 (10), 2047, 2013.

26. KIM B., GAUTIER M., PROST B., MOLLE P., MICHEL P., GOURDON R. Performance evaluation of partially saturated vertical-flow constructed wetland with trickling filter and chemical precipitation for domestic and winery wastewaters treatment. Ecological Engg. 71, 41, 2014.

27. KHAN Z., NAZ I., REHMAN A., RAFIQ M., ALI N., AHMED S. Performance efficiency of an integrated stone media fixed biofilm reactor and sand filter for sewage treatment. Desalination and Water Treatment. 54 (10), 2638, 2015.

28. ZHANG Y., YAN C., CHUNPING Y., WEI L., GUANGMING Z., LI L. Performance of system consisting of vertical flow trickling filter and horizontal flow multisoil-layering reactor for treatment of rural wastewater. Bioresource Tech. 193, 424, 2015.

29. HONGLEI W., GUODONG J., XUEYUAN B., CHUNGUANG $\mathrm{H}$. Assessing nitrogen transformation processes in a trickling filter under hydraulic loading rate constraints using nitrogen functional gene abundances. Bioresource Tech. 177, 217, 2015.

30. XINYING Z., JIE L., YANGBO Y., RANRAN X., ZHICHAO W. Biofilm characteristics in natural ventilation trickling filters (NVTFs) for municipal wastewater treatment: Comparison of three kinds of biofilm carriers. Biochem. Engg. J. 106, 87, 2016

31. LEI M., BEN V.D.A., JUN D., RAI S., KOOKANA., HOWARD F. Impact of exogenous organic carbon on the removal of chemicals of concern in the high rate nitrifying trickling filters. J. Enviro. Manag. 174, 7, 2016.

32. LI W., LOYOLA L.C., CROWLEY D.E., AHMAD Z. Performance of a two phase biotrickling filter packed with biochar chips for treatment of wastewater containing high nitrogen and phosphorus concentrations. Process Safety and Environment Protection. 2016

33. HAO W., ZHENHAO Y., YUE Q., YINGYU F., CHENGRI Y. Removal of methyl acrylate by ceramic-packed biotrickling filter and their response to bacterial community. 
Bioresource Tech. 209, 237, 2016.

34. CAO Q., XIE K.C., LV Y.K., BAO W.R., Process effects on activated carbon with large specific surface area from corn cob. Bioresour. Technol. 97 (1), 110, 2006.

35. GRAHAM R.L., NELSON R., SHEEHAN J. Current and potential U.S. corn Stover supplies. Agron. J. 99 (1), 1, 2007.

36. MUTHUSAMY P., MURUGAN S., MANOTHI S. Removal of nickel ion from industrial wastewater using maize cob. ISCA J. Biol. Sci. 1 (2), 7, 2012.

37. APHA. Standard methods for the examination of water and wastewater. 22 $2^{\text {th }}$ edition, American Public Health Association: Washington D.C. 2012.

38. KORNAROS M., LYBERATOS G. Biological treatment of wastewaters from a dye manufacturing company using a trickling filter. J. Hazard. Mater. 136 (1), 95, 2006.

39. WIJEYEKOON S., MINO T., SATOH H. Effects of substrate loading rate on biofilm structure. Water Res. 38 (10), 2479, 2004.

40. PEARCE P., WILLIAMS S. A nitrification model for mineral-media trickling filters. Water Environ. J. 13 (2), 84, 2007.

41. NAZ I., DEVENDRA P.S., SADIA M., NAEEM A., SAFIA A. Assessment of biological trickling filter systems with various packing materials for improved wastewater treatment. Environ. Tech. 36 (4), 424, 2014.

42. NAZ I., SHAMA S., IRUM P., DEVENDRA P.S., SAFIA A. Physiological activities associated with biofilm growth in attached and suspended growth bioreactors under aerobic and anaerobic conditions. Environ. Tech. 36 (13), 1657, 2015.

43. TAKEYUKI S., SIRIWAT J., TOSHIHIRO H. Removal of ammonia from contaminated air in a biotrickling filterDenitrifying bioreactor combination system. Water Res. 42 (17), 4507, 2008.

44. HUANGL., XUAN C., YULEIZ. Performance of sequencing microbead biofilters in a recirculating aquaculture system. Aqua. Eng. 52, 80, 2013.

45. MARCIN Z., MAGDALENA Z., MARCIN D. Application of microwave radiation to biofilm heating during wastewater treatment in trickling filters. Bioresour. Technol. 127, 223, 2013.

46. RAVI K.B., LAKSHMI P.M., SRINIVASA R.D., SAMBASIVA R.K.R.S. Bioremediation of Sewage using Specific Microbial consortium and Biogenic Filter materials. Indian J. Res. 2, 2013.

47. ABDUL R., IFFAT N., ZIA U.K. Sequential application of plastic media-trickling filter and sand filter for domestic wastewater treatment at low temperature condition. Bri. Biotechnol. J. 2 (4), 179, 2012.

48. ZIA U.K., NAZ I., ABDUL R., MUHAMMAD R., NAEEM A., SAFIA A. Performance efficiency of an integrated stone media fixed biofilm reactor and sand filter for sewage treatment. Desalination and Water Treatment. 2014.

49. PITCHARD M., MKANDAWIRE T., NEILL J.G.O. Biological, chemical and physical drinking water quality from shallow wells on Malawi: Case study of Blantyre, Chiradzulu and Mulanje. Phy. Chem. Earth. 32 (15-18), 1167, 2007.

50. GARCIA M.J.J., POYATOS J.M., HONTORIA E. The influence of biofilm treatment systems on particle size distribution in three wastewater treatment plants. Wat. Air Soil Pollut. 212 (1/4), 37, 2010.

51. YASAR A., AHMAD., CHAUDHRY M.N., REHMAN M. S.U., KHAN A.A.A. Ozone for Color and COD Removal of Raw and Anaerobically Biotreated Combined Industrial Wastewater. Polish J. of Environ. Stud. 16 (2), 289, 2007.

52. KLIMIUK E., FILIPKOWSKA U., LIBECKI B. Coagulation of Wastewater Containing Reactive Dyes with the Use of Polyaluminium Chloride (PAC). Polish J. of Environ. Stud. $8(2), 81,1999$.

53. SADIA M., NOSHABA H.M., IFFAT N., SAFIA A. Decolonization of textile dye reactive blue 221 by bacterial isolated from anthropogenic dye-contaminated soil. Polish J. of Environ. Stud. 24 (4), 1705, 2015.

54. TORSTEN W. Adsorption and denitrification in nitrifying trickling filters. Water Res. 33 (6), 1500, 1999. 
